ENCYCLOPEDIA OF ISLANDS 


\section{ENCYCLOPEDIA OF ISLANDS}

EDITED BY

ROSEMARY G. GILLESPIE

University of California, Berkeley

DAVID A. CLAGUE

Monterey Bay Aquarium Research Institute

吕

UNIVERSITY OF CALIFORNIA PRESS

Berkeley Los Angeles London 
University of California Press, one of the most distinguished university presses in the United States, enriches lives around the world by advancing scholarship in the humanities, social sciences, and natural sciences. Its activities are supported by the UC Press Foundation and by philanthropic contributions from individuals and institutions. For more information, visit www.ucpress.edu.

Encyclopedias of the Natural World, No. 2

University of California Press

Berkeley and Los Angeles, California

University of California Press, Ltd.

London, England

(C) 2009 by the Regents of the University of California

Library of Congress Cataloging-in-Publication Data

Encyclopedia of islands / edited by Rosemary G. Gillespie and David A. Clague.

p. cm. - (Encyclopedias of the natural world ; 2)

Includes bibliographical references and index.

ISBN 978-0-520-25649-I (cloth : alk. paper)

I. Islands-Encyclopedias. I. Gillespie, Rosemary G., I957-

II. Clague, D. A.

GB471.E53

$55 \mathrm{I} .4203-\mathrm{dc2} 2$

2009

Printed in China

I6 I5 14 I3 12 II IO 09

IO $\quad 9 \begin{array}{lllllllll} & 8 & 7 & 6 & 5 & 4 & 3 & 2 & \text { I }\end{array}$

The paper used in this publication meets the minimum requirements of ANSI/NISO Z39.48-I992 (R 1997) (Permanence of Paper).\{infcir\}

Cover photograph: Mercherchar Island, Palau, courtesy Patrick L. Colin. Insets, from left: Lava from Piton de la Fournaise, Rèunion, (C) KM

KRAFFT/CRI-Nancy-Lorraine, used with permission; Greene's dudleya

(Dudleya greenei) on Santa Cruz Island, (C) Kathy deWet-Oleson; male orange dove (Chrysoenas victor), endemic to Fiji, courtesy Paddy Ryan; aerial view of Bermuda, courtesy Bermuda Zoological Society (see also frontispiece). 